\title{
The Levels of Plastic-associated Heterotrophic Bacteria on Three Different Types of Plastics
}

\author{
Pelin Saliha Çiftçi Türetken ${ }^{1}$ (D), Gülşen Altuğ ${ }^{1}$ (D), Turgay Öksüzoğlu² (D)
}

Cite this article as: Çiftçi Türetken, PS., Altuğ, G., Öksüzoğlu, T. (2020). The levels of plastic-associated heterotrophic bacteria on three different types of plastics. Aquatic Sciences and Engineering, 35(2), 31-35.

ORCID IDs of the authors: P.S.C.T. 0000-0002-4377-1628; G.A. $0000-0003-3251-7699$ T.Ö. 0000-0003-2360-9444

${ }^{1}$ Istanbul University, Faculty of Aquatic Sciences, Department of Marine Biology, Istanbul, Turkey

${ }^{2}$ Istanbul University, Institute of Graduate Studies in Sciences, Department of Marine Biology, Istanbul, Turkey

\section{Submitted:}

21.06.2019

Revision Requested: 25.11.2019

Accepted:

14.01.2020

Online published:

24.01.2020

Correspondence:

Pelin Saliha Çiftçi Türetken

E-mail:

pciftci@istanbul.edu.tr

(C) Copyright 2020 by Aquatic Sciences and Engineering Available online at

https://dergipark.org.tr/ase

\begin{abstract}
Plastic pollution in marine ecosystems is one of the most important study topics in recent years. The toxicity, mobility and long-term persistence characteristics of plastics create risk in ecosystems, biota and human health. In this study, the levels of heterotrophic bacteria attached to the surfaces of commonly used plastic types; polyvinylchloride (PVC), polyethylene (PE), and polypropylene (PP) were tested in a mechanical experimental system prepared with seawater under controlled conditions in laboratory. The seawater, which was used in the experimental system, was taken under aseptic conditions from the Golden Horn Estuary, located in the Istanbul region of Turkey. Three different types of plastic (PVC, PE and PP), in two different (glass slide $(76 \times 26 \mathrm{~cm})$ and virgin micro pellets $(5 \mathrm{~mm}$ diameter) size, were placed in the experiment setup filled with seawater and incubated for 28 days at ambient temperature. At the end of 28 days, the counts of heterotrophic bacteria were tested using the spread plate technique on Marine Agar (Difco), in both plastic surfaces and surrounding seawater. The levels of heterotrophic bacteria were recorded to be lower in the seawater surrounding the micropellets and lam-size plastic samples. The seawater sample bacterial levels were recorded as $12 \times 10^{9} \mathrm{CFU} / \mathrm{ml}$, at the start of the experiment. At the end of the $28^{\text {th }}$ days, it was recorded to be $83 \times 10^{9} \mathrm{CFU} / \mathrm{ml}$. The highest levels of heterotrophic bacteria were recorded as $41 \times 10^{10} \mathrm{CFU} / \mathrm{cm}^{-2}$ and $61 \times 10^{10} \mathrm{CFU} / \mathrm{cm}^{-2}$ on the lam-size surfaces and the micropellet surface of the polypropylene samples, respectively. In the experiments, the PP plastic type has been recorded as a more preferred plastic derivative by heterotrophic bacteria according to the PVC and PE plastic types, but there has been no significant difference in the bacterial adhesion rates on the surfaces. The study contributed increasing knowledge on the bacterial approach to microplastics types. However, there is a need for long term studies related to the mechanism of bacteria attached to microplastics.
\end{abstract}

Keywords: Microplastic, heterotrophic bacteria, polyvinylchloride, polyethylene, polypropylene

\section{INTRODUCTION}

Plastics are synthetic polymers with high insulation against electricity and heat, light, easy to operate structure, and are used in many areas in our daily lives. With the development of synthetic organic polymers in the mid-twentieth century, plastic production in 1950, which was 1.5 million tons per year, exceeded 300 million tons over the years. It is expected to reach 540 million tons in 2020, with the increase in production and consumption (Haward, 2018). Most polymer species are highly persistent in the marine ecosystem. Only when exposed to ultra-violet radiation, they undergo photo catalysis and slowly dissolve. Plastic waste can be of any size, from visible large particles to invisible small particles.

On a global scale, it is estimated that 1.5 million tons of primary plastic are dumped into the 
oceans (0.8 million tons/year in the optimist scenario, 2.5 million tons/year in the pessimistic scenario). $98 \%$ of the primary microplastic reaching the sea constitutes terrestrial activities and $2 \%$ from the activities carried out at sea (Boucher \& Friot, 2017). In terrestrial activities, the ratio of those arriving by road transport is $49 \%$, the ratio of those involved by waste water treatment plants is $25 \%$, and the ratio of those transported by wind is $7 \%$.

It is known that microplastics can absorb contaminants in water, toxic compounds such as polychlorobifenil (PCB), and harmful compounds such as nonylphenol (International Pellet Watch, 2018). The release of microplastics with these contaminants in the aquatic environment causes serious effects on the transport of harmful compounds (Mato et al., 2001; Endo et al., 2005).

In addition to the planktonic form, it has been determined that bacteria, known to survive in water as individuals, have developed a different structure in the form of a community in order to continue their lives, as seen in the studies and observations carried out over time (Çiftçi, 2005). The demands of bacteria to hold onto any surface around the sea are intended to evaluate organic matter. The particles of the bacterium called "attachment bacteria" have been identified more intensively than the bacteria that live freely in surface water (Costa, 2011). It is known that microplastics in the marine ecosystem form a suitable environment for bacteria to hold on.

Plastisphere is a term used to describe the habitats on plastics in aquatic ecosystems. The initiation of this mechanism, which is formed by microorganisms, which develops in all kinds of materials, and which is defined as "biofouling", is the attachment of gram negative bacteria to the environment, and then diatoms, protozoa and invertabrates are added to this structure. The long-term permanence of plastics in the marine ecosystem and the transport of bacteria and other microorganisms due to currents causes them to reach different marine areas as invasive species (Zettler et al., 2013; Pauli et a., 2017; Gündoğdu et al., 2017; Hodgson et al., 2018; Rech et al., 2018). These structures formed on plastics increase the weight of micro-macroplastics, and cause them to be transported from surface to bottom in aquatic ecosystems (Kaiser et al 2017; Kooi et al., 2017). For this reasons, the determination of bacterial levels on microplastic surfaces is very important.

The main reason why plastic is widely talked about today and in every aspect of human life is the fact that plastics are not easily degraded and are resistant in nature (Shah et al., 2008; Shimao, 2001). It is known that microorganisms, especially bacteria, are adaptable to ecological niches and natural habitats. The rapid adaptation of microorganisms is also applied to exist in the artificial habitat called Plastic in the oceans. Microbial colonization on the plastic particle in the ocean was reported for the first time in 1972 (Carpenter et al., 1972; Carpenter et al., 1972). Floating plastic parts in the ocean provide an environment for microorganisms to attach (Chen and He, 2015).

The attachment of bacteria to cling to any surface in order to evaluate the nutrients in the environment is more than their tendency to live freely. These tendencies settle on different surfaces in the marine environment and prepare the ground for the col- lection of bacterial communities. The localization of other microorganisms is a process related to the intensity of the initial bacteria (Hall-Stoodley et al., 2004). There are studies evaluating the binding rates of bacteria depending on the materials. The studies on this subject indicate that the different media characteristics will also be different (Donlan, 2002; Davey and O'toole, 2000).

In this study, the aim is to obtain preliminary data related to the levels of free living and plastic-associated bacteria, using the macro (glass slide size) and micro dimensions of three types of plastics (polyvinylchloride, polyethylene, polypropylene) which are used frequently in Turkey.

\section{MATERIALS AND METHODS}

The surface $(0-30 \mathrm{~cm})$ seawater sample was taken from Karaköy Port Town in February 2018, under aseptic conditions. The sampling point is shown in Figure 1. The sample was brought to the Istanbul University, Faculty of Aquatic Sciences, with the cold chain on the same day.

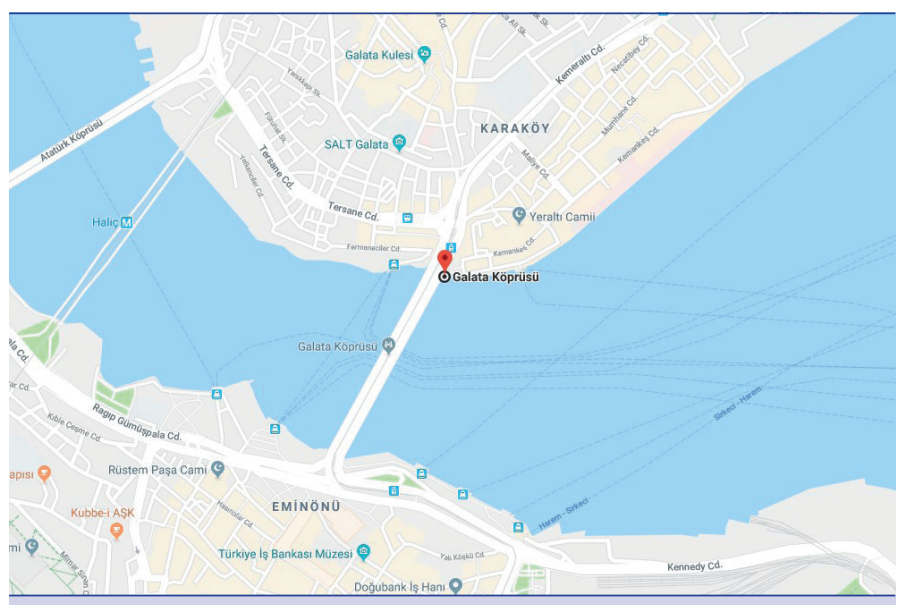

Figure 1. Sampling Point.

\section{Preparation of experimental setup}

The experimental devices were prepared in two different ways. The most common used three plastic types were chosen, and they were purchased from a plastic factory. The plastics size tested were arranged considering the experimental setup measurement as glass slide size and $5 \mathrm{~mm}$ diameter of micropellet. Similar size materials were used to calculate and compare the area where the bacteria attached. All sizes of polyvinylchloride (PVC), Polyethylene (PE) and Polypropylene (PP) materials were prepared for analysis according to Palanichamy (2002). A 15-liter sea water sample was put into the special design closed circuit system. PVC, PE, PP materials were cut to glass slide $(76 \times 26 \mathrm{~mm})$ size, and they were sterilized by washing with sterile distilled water. They were placed in the closed circuit system under aseptic conditions to avoid airborne bacterial contamination, and the water circulation rate was set to $13 \mathrm{~Hz}$ (Hi-RUN / N100) (Figure 2).

In addition, the $100 \mathrm{ml}$ of seawater samples were introduced into the sterile Erlenmeyer $(250 \mathrm{ml})$ under aseptic conditions. All the micropellet size samples ( $5 \mathrm{~mm}$ in diameter) were weighed as $1 \mathrm{~g}$ un- 
der aseptic conditions, and they were placed in the Erlenmeyer containing seawater. The samples were placed in a shaking incubator, and were incubated at ambient temperature for 28 days (Figure 3).

\section{Bacteriological analysis}

The method of spreading plaque to Marine Agar (Difco) was used to determine the heterotrophic bacteria levels in plastic surfaces and the seawater. The Petri dishes were incubated at

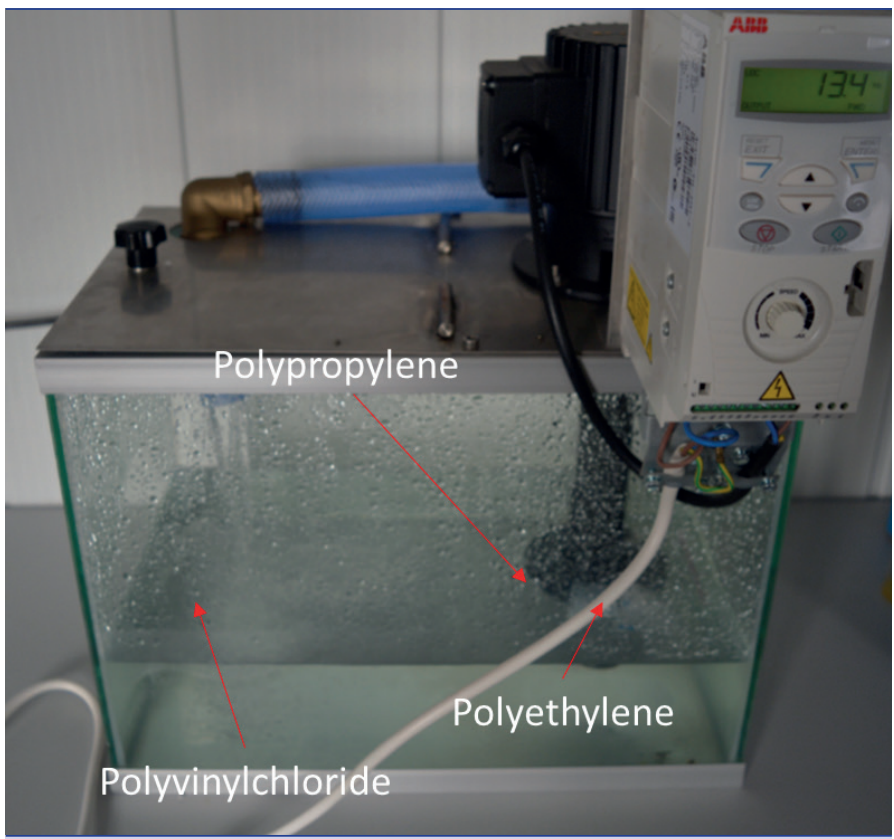

Figure 2. The special design closed circuit system.

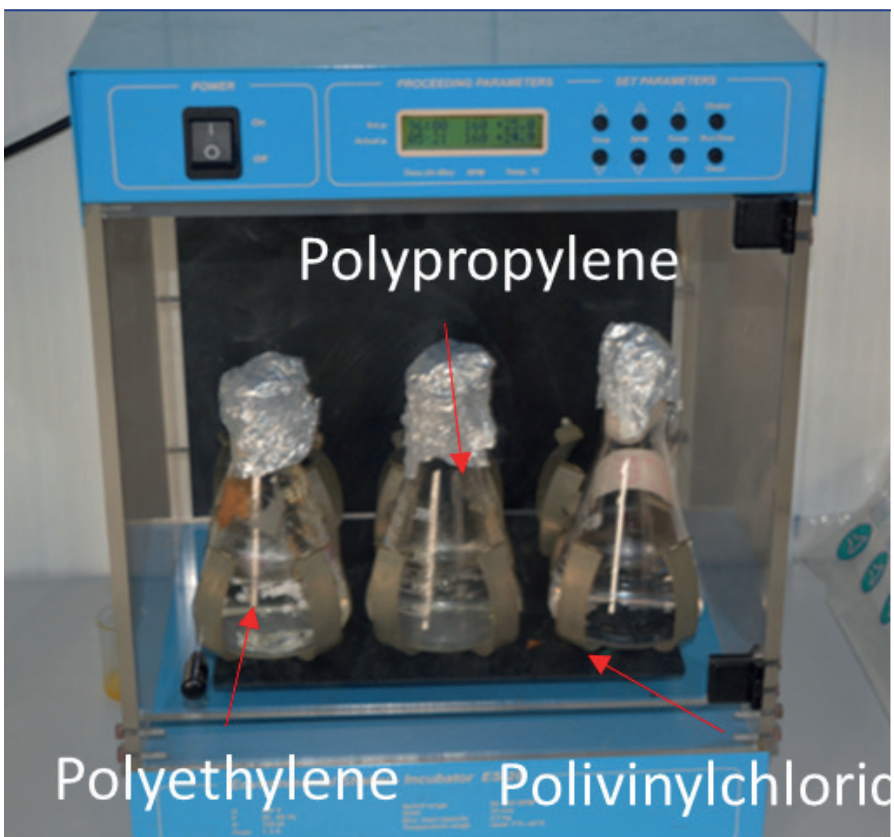

Figure 3. The shaking incubator used in the experiment. least $48-72$ hours at $22 \pm 1{ }^{\circ} \mathrm{C}$. The colony count was carried out and recorded at the end of incubation. All bacteriological analyses were performed in triplicate (APHA, 1998). The first day of bacterial level results were recorded as the bacterial level of the control group, and this data were used to compare the results obtained from the plastic surfaces after the system was shut down (Bordalo et al., 2002).

\section{Statistical analysis}

Plastic types and bacterial level were compared by one-way ANOVA, followed by Tukey's post-hoc tests. The plastic size and bacterial level tested with one-way ANOVA. Statistical analysis was performed with the SPSS Statistics 21 program.

\section{RESULTS AND DISCUSSION}

The results of the first day and last day heterotrophic bacteria levels obtained from the plastic (glass slide size [76 $\times 26 \mathrm{~mm}]$ and micropellet-size [ $5 \mathrm{~mm}$ in diameter]) samples were summarized in Table 1 and Figure 4.

The results of the first day and last day heterotrophic bacteria levels obtained from the sea water samples were summarized in Table 2 and Figure 5.

Table 1. Heterotrophic Bacterial Levels data obtained from plastic samples

\begin{tabular}{cccc}
\hline & & \multicolumn{2}{c}{ Incubation Time } \\
\cline { 3 - 4 } & & $1^{\text {st }}$ day & $2^{\text {th }}$ day \\
\hline Size & Type & & CFU/cm ${ }^{-2}$ \\
\hline Glass Slide & PVC & - & $45 \times 10^{10}$ \\
& PP & - & $65 \times 10^{10}$ \\
Micropellet & PE & - & $60 \times 10^{10}$ \\
& PVC & - & $48 \times 10^{10}$ \\
& PP & - & $97 \times 10^{10}$ \\
& PE & - & $87 \times 10^{10}$
\end{tabular}

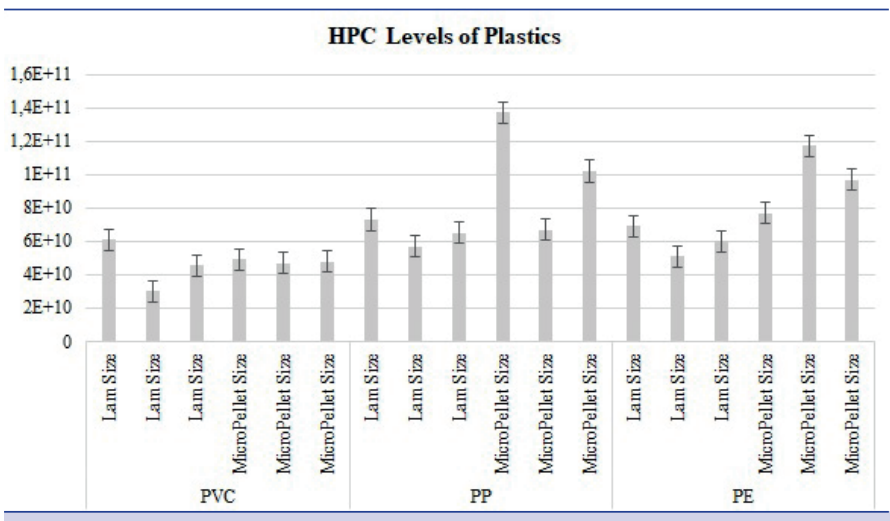

Figure 4. Heterotrophic Bacterial Levels data obtained from plastic samples. HPC: Heterotrophic Bacterial Count 
Table 2. Heterotrophic Bacterial Levels obtained from the sea water samples

\begin{tabular}{lccc}
\hline & & \multicolumn{2}{c}{ Incubation Time } \\
\cline { 3 - 4 } & & $\mathbf{1}^{\text {st }}$ day & $\mathbf{2 8}^{\text {th }}$ day \\
\cline { 3 - 4 } & & \multicolumn{2}{c}{ CFU/ml } \\
\hline Glass Slide Size & Sea Water & $12 \times 10^{9}$ & $83 \times 10^{9}$ \\
\hline \multirow{2}{*}{ Micropellet Size } & Sea Water (PVC) & $12 \times 10^{9}$ & $20 \times 10^{9}$ \\
& Sea Water (PE) & $12 \times 10^{9}$ & $86 \times 10^{9}$ \\
& Sea Water (PP) & $12 \times 10^{9}$ & $42 \times 10^{9}$
\end{tabular}

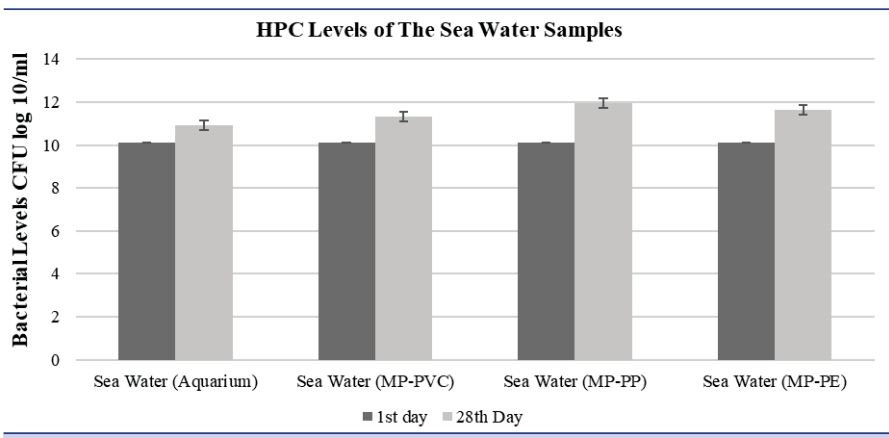

Figure 5. The levels of heterotrophic bacteria obtained from the seawater samples at the first and the end of the experiments. HPC: Heterotrophic Bacterial Count

The bacteria levels were found as $45 \times 10^{10} \pm 2.8 \mathrm{CFU} / \mathrm{cm}^{2}$, $65 \times 10^{10} \pm 4.9 \mathrm{CFU} / \mathrm{cm}^{2}$ and $60 \times 10^{10} \pm 5.4 \mathrm{CFU} / \mathrm{cm}^{2}$, respectively, in the glass slide size samples of PVC, PP and PE surfaces. The highest bacterial adhesion rate to glass slide size was detected on the polypropylene (PP) surface. The mean levels of bacteria detected in the PVC, PP and PE micro-pellets was $48 \times 10^{10} \pm 3.2$ $\mathrm{CFU} / \mathrm{cm}^{2}, 97 \times 10^{10} \pm 4.7 \mathrm{CFU} / \mathrm{cm}^{2}$, and $87 \times 10^{10} \pm 5.5 \mathrm{CFU} / \mathrm{cm}^{2}$, respectively, as a result of the 28-day incubation in a shaking incubator. The mean bacterial levels of the seawater including PVC, PP, PE micro pellet were determined as $20 \times 10^{9} \pm 8.2 \mathrm{CFU} / \mathrm{ml}$, $86 \times 10^{9} \pm 8.2 \mathrm{CFU} / \mathrm{ml}$ and $42 \times 10^{9} \pm 8.2 \mathrm{CFU} / \mathrm{ml}$, respectively.

The highest total mesophilic aerobic bacteria level was detected on the micro and macro sized polypropylene (PP) plastic surfaces. This finding has shown that the polypropylene plastic variety for the adhesion of bacteria has the appropriate surface and, it was found that there was a statistically significant relationship between the plastic type and the levels of bacteria $(p<0.05)$.

Microplastic pellets have higher levels of bacteria than the glass slide size samples $(p<0.05)$. This situation is related to the fact that the surface area is larger in the pellet samples. Similarly, Carson et al. (2013) compared microbial colonization on polypropylene, polystyrene and polyethylene in the North Pacific using scanning electron microscopy, and recorded the highest micro- bial abundance on large surface areas of polystyrene foam. Researches on microbial biofilms on plastic wastes in water have begun to be the subject of more studies in recent years (Davey and O'toole, 2000; McKenney et al., 1998; Muthukumar \& Veerappapilla, 2015; Oberbeckmann et al., 2018; Zettler et al., 2013).

Lobelle and Cunliffe (2011) reported that biofilm formation was observed in sinking plastics with early stage biofilm formation on marine microplastic wastes. In the first week of the study, while the number of cultivable heterotrophic bacteria on the plastic surface was $1.4 \times 10^{4} \mathrm{~cm}^{-2}$, it reached $1.2 \times 10^{5} \mathrm{~cm}^{-2}$ at the end of the third week. They also did not encounter a species that degrades plastic in early stage biofilm formation (Lobelle and Cunliffe, 2011). The average level of heterotrophic bacteria was reported in the range of 6.4-7.9 CFU/ $\mathrm{cm}^{2}$ in the study conducted on sheet metal, aluminum, stainless steel, glass, galvanized, wood, cotton and rope (Altuğ et al., 2007). In this study, the heterotrophic bacterial levels on PP, PVC and PE surfaces were determined at an average of $11 \mathrm{CFU} / \mathrm{cm}^{2}$. Zettler et al. (2013) reported that the microbial community on polypropylene and polyethylene particles differed from the community in seawater. In our study, we can sort the plastic varieties according to the bacterial levels they have on them as PP>PE>PVC. The research conducted by Oberbeckmann et al. (2018) examined the microbial biofilm structure and variety on marine microplastics in North European waters in different seasons.

The sector produced 3.5 million tons of plastic raw materials in 2017, and produced around 1.8 million tons in the first 6 months of 2018 all over the world. In Turkey, the total plastic raw materials production was realized at the following rates: low-density polyethylene (31\%), high-density polyethylene (9\%), PVC (15\%), PP (\%12), PS (10\%), and Polyethylene terephthalate (23\%) (AT\&T, 2017).

The part of the plastic that is produced in the scope of recycling is not clearly predictable. Plastics such as disposable bags, PET bottles and packaging are known to play a major role as contaminants for our aquatic resources (Browne et al., 2011; Yurtsever, 2015).

\section{CONCLUSION}

This research confirms that the plastic surfaces, like all particles in marine ecosystems, might have a potential to carry microbial agents. The domestic and industrial wastes should be prevented from reaching the sea, permanent pollutant sources should be identified and the monitoring studies should be carried out in marine ecosystems. Alternative organic materials should be preferred instead of disposable plastic materials. This study contributes scientific knowledge related for the first time to the levels of heterotrophic bacteria, attached to the plastic surfaces, in our country. Detailed and long-term studies are needed to determine the bacterial profiles and metabolical peculiarities of dominant bacterial species that hold onto plastic surfaces.

Acknowledgment: The authors would like to thank Meryem ÖZTAS (MSc), and S. Dilara KARAMAN for their laboratory assistance. 
Ethics committee approval: Ethics committee approval is not required.

Conflict of Interests: There are no conflicts of interest to declare.

\section{REFERENCES}

Altuğ, G., Çardak, M., Çiftci, P. S., Gürün, S. (2007). Levels of Heterotrophic Aerobic Bacteria Isolated from Bacterial Biofilm Layer on Various Materials, Turkish Journal of Aquatic Life, 3-5(5-8), 561-566.

APHA (1998). Standard Methods for the Examination of Water and Wastewater 20th Edition. Clesceri, L. S., A. E Greenberg and A.D Eaton (eds). American Public Health Association, American Water Works Association and Water Environment Federation. Washington, D.C.

AT\&T (2017). 'Plastik Sektörü, Ekonomik Araştırmalar Departmanı, Web sitesi: https://www.atbank.com.tr/documents/PLASTIK\%20SEKTORU _MAYIS\%202017.PDF [accessed 17.05.2018] (In Turkish).

Bordalo, A. A., Onrassami, R., Dechsakulwatana, C. (2002). Survival of faecal indicator bacteria in tropical estuarine waters (Bangpakong River, Thailand). Journal of Applied Biology, 93(5), 864-871. [CrossRef]

Boucher, J. and Friot D. (2017). Primary Microplastics in the Oceans: A Global Evaluation of Sources. Gland, Switzerland: IUCN. 43pp. [CrossRef]

Browne, M. A., Crump, P., Niven, S. J., Teuten, E. L., Tonkin, A., Galloway, T., Thompson, R.C. (2011), Accumulations of Microplastic on Shorelines Worldwide: Sources and Sinks, Environmental Science \& Technology, 45, 9175-9179. [CrossRef]

Carpenter, E. J., Anderson, S. J., Harvey, G. R., Miklas, H. P., Peck, B. B. (1972). Polystyrene spherules in coastal waters. Science, 178(4062), 749-750. [CrossRef]

Carpenter, E. J., Smith, K. L Jr. (1972). Plastics on the Sargasso sea surface. Science, 175(4027), 1240-1241. [CrossRef]

Carson, H. S., Nerheim, M. S., Carroll, K. A., Eriksen, M. (2013). The plastic-associated microorganisms of the North Pacific Gyre, Marine Pollution Bulletin, 75(1-2), 126-132. [CrossRef]

Chen, K., He, R. (2015). Mean circulation in the coastal ocean off northeastern North America from a regional-scale ocean model, Ocean Science, 11, 503-517. [CrossRef]

Costa, F., Costa, E., Campos, L. (2011). Plastics in The Antarctic Environment: Are We Looking Only at The Tip of The Iceberg?, Oecologia Australis, 15(1), 150-170. [CrossRef]

Çiftçi, Z. (2005). Kronik tonsilitte biyofilmin rolü [Uzmanlık Tezi]. İstanbul, Taksim Eğitim Araştırma Hastanesi KKB Kliniği.

Davey, M. E., O'toole, G. A. (2000). Microbial Biofilms: From Ecology To Molecular Genetics. Microbiology and Molecular Biology Reviews, 64(4): 847-848. [CrossRef]

Donlan, R. M. (2002). Biofilms: Microbial Life on Surfaces, Emerging Infectious Diseases, 8(9), 881-890. [CrossRef]

Endo, S., Takizawa, R., Okuda, K., Takada, H., Chiba, K., Kanehiro, H., Ogi, H.,Yamashita, R., Date, T. (2005). Concentration of polychlorinated biphenyls (PCBs) in beached resin pellets: Variability among individual particles and regional differences. Marine Pollution Bulletin, 50(10), 1103-1114. [CrossRef]
Gündoğdu, S., Çevik, C., Karaca, S. (2017). Fouling assemblage of benthic plastic debris collected from Mersin Bay, NE Levantine coast of Turkey. Marine Pollution Bulletin, 124(1), 147-154. [CrossRef]

Hall-Stoodley, L., Costerton, J. W., Stoodley, P. (2004). Bacterial biofilms: from the natural environment to infectious diseases, Nature Reviews Microbiology, 2(2), 95-108. [CrossRef]

Haward, M. (2018). Plastic pollution of the world's seas and oceans as a contemporary challenge in ocean governance. Nature Communications, 9, 667. [CrossRef]

Hodgson, D. J., Bréchon, A. L., Thompson, R. C. (2018). Ingestion and fragmentation of plastic carrier bags by the amphipod Orchestia gammarellus: Effects of plastic type and fouling load. Marine Pollution Bulletin, 127, 154-159. [CrossRef]

International Pellet Watch. (2018). Pollutants in Pellet, Web adresi: http:// www.pelletwatch.org/en/pollutants.html [accessed 28.02.2018]

Kaiser, D., Kowalski, N., Waniek, J. J. (2017). Effects of biofouling on the sinking behavior of microplastics. Environmental Research Letters, 12(12), 1-10. [CrossRef]

Kooi, M., Nes, E. H., Scheffer, M. Koelmans, A. (2017). Ups and Downs in the Ocean: Effects of Biofouling on Vertical Transport of Microplastics. Environmental Science \& Technology, 51(14), 7963-7971. [CrossRef]

Lobelle, D., Cunliffe, M. (2011). Early microbial biofilm formation on marine plastic debris. Marine Pollution Bulletin, 62(1), 197-200. [CrossRef]

Mato, Y., Isobe, T., Takada, H., Kanehiro, H., Ohtake, C., Kaminuma, T. (2001). Plastic Resin Pellets as a Transport Medium for Toxic Chemicals in the Marine Environment. Environmental Science \& Technology, 35(2), 318-324. [CrossRef]

Mckenney, D., Hübner, J., Muller, E., Wang, Y., Goldmann, D.A., Pier, G. B. (1998). The ica locus of Staphylococcus epidermidis encodes production of the capsular polysaccharide/adhesin, Infection and Immunity, 66(10), 4711-4720. [CrossRef]

Muthukumar, A., Veerappapillai, S. (2015). Biodegradation of Plastics, A Brief Review, International Journal of Pharmaceutical Sciences Review and Research, 31(2), 204-209.

Oberbeckmann, S., Kreikemeyer, B., Labrenz, M. (2018). Environmental Factors Support the Formation of Specific Bacterial Assemblages on Microplastics. Frontiers in Microbiology, 8(2709), 1-12. [CrossRef]

Palanichamy, S., Maruthamuthu S, Macickam, S. T., Rajendran, A. (2002). Microfouling of manganese-oxidizing bacteria in Tuticorin harbour waters, Current Science, 82(7), 865-869.

Pauli, N. C., Petermann, J. S., Lott, C., Weber, M. (2017). Macrofouling communities and the degradation of plastic bags in the sea: An in situ experiment. Royal Society Open Science, 4(10), 1-10. [CrossRef]

Rech, S., Thiel, M., Borrell, P., Yaisel J., García-Vazquez, E. (2018). Travelling light: Fouling biota on macroplastics arriving on beaches of remote Rapa Nui (Easter Island) in the South Pacific Subtropical Gyre. Marine Pollution Bulletin, 137, 119-128. [CrossRef]

Shah, A. A., Hasan, F., Hameed, A., Ahmed, S. (2008). Biological degradation of plastics: a comprehensive review., Biotechnology Advances, 26(3), 246-265. [CrossRef]

Shimao, M. (2001). Biodegradation of plastics., Current Opinion in Biotechnology, 12(3), 242-247. [CrossRef]

Yurtsever, M. (2015). Microplastics: An Overview, İzmir Üniversitesi Fen ve Mühendislik Dergisi, 17(50), 68-83.

Zettler, E. R., Mincer, T. J., Zettler, L. A. A. (2013). Life in the "Plastisphere": Microbial Communities on Plastic Marine Debris. Environmental Science \& Technology, 47(13), 7137-7146. [CrossRef] 